\title{
The Difference Denominations Made: Identifying the Black Church(es) and Black Religious Choices of the Early Republic
}

\author{
Kyle T. Bulthuis
}

Richard Allen was not a man to beat around the bush. When confronted with injustice, Allen boldly charged forward for what he believed right. In 1792, Allen and his colleague, Absalom Jones, were dragged from their knees while at prayer at Philadelphia's St. George's Methodist Church. Jones and Allen had lingered while Methodist preachers attempted to serve communion to white members; church elders expected black members to retreat until all whites had been served. Allen led blacks out of St. George's, and toward the creation of the African Methodist Episcopal Church, the first and most prominent of the antebellum black Christian denominations. Allen remained a leading figure of the free black community in Philadelphia and of black communities nationally. Consequently, historian Richard Newman has deemed Allen a Founding Father, one no less responsible for the creation of the American Republic than the well-heralded white founders Washington, Jefferson, or Adams. ${ }^{1}$

The story of Allen's departure from St. George complements the narrative of black independence, and thus black empowerment. Events surrounding Allen's dramatic departure highlight a less-emphasized aspect of his life; also known to Allen's biographers, but less trumpeted, was his staunch identification with Methodism, even when it required separation from other blacks. Before the break with St. George, Allen and Jones had joined Philadelphia's nondenominational Free African Society. Allen left the group shortly after its founding, as he was unwilling to compromise his Methodist principles or desire to proselytize for the Methodist faith. After Allen and Jones led the walkout at St. George's, Philadelphia's Protestant Episcopal Church approached the men with the promise of a church

Religion and American Culture: A Journal of Interpretation, Vol. 29, Issue 2, pp. 255-290, ISSN: 10521151, electronic ISSN: 1533-8568. () 2019 by The Center for the Study of Religion and American Culture. All rights reserved. Please direct all requests for permission to photocopy or reproduce article content through the Cambridge University Press's Rights and Permissions web page, https://www.cambridge.org/about-us/rights-permissions. DOI: https://doi.org/10.1017/rac.2019.3. 
building, provided the men become Episcopalian. Jones acceded, but Allen demurred, again unwilling to compromise his Methodist identity. ${ }^{2}$ Allen was, first and foremost, a Methodist. Why that matters sheds light on the significance of the black church in American history, a significance that has faded in recent historiographical debates.

It has become a truism to assert that the black church has been central to black life in America. Buoyed in part by mental images of the Montgomery bus boycott in 1955 or the March on Washington in 1963, the American historical narrative generally assumes that a fundamental, basic, connection links the black church to the black community. In this attractive package, what was once an act of civil disobedience in the collective American memory now looks like civil religion. ${ }^{3}$

The scholarly world is a bit more complicated. Church history in general has fallen out of favor, in part because its methodology is institutionally driven, top-down and elitist, overly masculine and heteronormative, tuned to clerical interests, focused on theology, and generally triumphalist. Although studies of black churches have fared a bit better, recent scholars have similarly questioned the significance of the black church as a historical field, in part because anthropological, gendered, or political approaches promised to yield richer results. A few scholars have gone so far as to sound a death knell for the study of the black church. ${ }^{4}$

Although the black church as a single, unitary concept may have lost its value, a consideration of black church history should not. Richard Allen's choice to remain a Methodist, and, in so doing, to become an African Methodist, was undoubtedly significant in the paths it traced in black history. Allen did not so much create the black church, but a black church; Allen and Jones, in part, contributed individually to a plural creation of black churches. A consideration of the black church as plural and multifaceted, I argue, will lead to a deeper understanding of African-American historical experience. $^{5}$

Some recent historical works have tended to downplay religion as a component of black religious identity, instead finding in the black community socioeconomic division, or within religious identity strong gendered and class divides. ${ }^{6}$ Works that do consider religion often tend to consider the black church as a single entity, assuming a singleness of purpose and linear trajectory toward reform. ${ }^{7}$ A consideration of black denominational choices-theological and religious identities - that coexisted alongside socioeconomic, racial, and reform communities yields a deeper and richer understanding of 
black antebellum experience. It reveals both positive and negative positions among black religious actors, as well as points of separation and cooperation between them.

In this essay, I sketch four different denominational traditions, representing blacks' major choices in religious affiliation in the nineteenth century: the Episcopalian, the Presbyterian and Congregational, the Methodist, and the Baptist. I focus on two major characteristics of each strain: the theological or religious imperatives of each denomination, and the institutional or ecclesiastical structures. This study is not meant to be exhaustive in either the bodies considered or the methods employed. ${ }^{8}$ The four groups represent the vast majority of recorded religious expressions for American blacks in the antebellum era. Drawing these distinctions for black Protestants may help us understand distinctions among other black religious groups, Christian and non-Christian, colonial and modern. Understanding these differences among otherwise similar religious groups also allows us to perceive the full range of historical experiences available to any group, white or black.

Within the antebellum era, this study suggests that black religious experiences were multifaceted, and that intellectual and social influences on black religion rarely worked in simple or linear ways. The intellectual and bureaucratic limits that each church's theology and organization created provided a possible framework within which churchgoers acted. Theology and ecclesiology served as brakes on some aspects of reform, and galvanized other forms of resistance, depending on the group. In general, I argue that the early dominance of Episcopalian and Presbyterian black church leaders, and the institutional and theological requirements that such leaders work closely with whites, helped ensure that uplift ideology was the driving force in early black reform. Although numerically dominant, black Methodists and Baptists did not initially dominate discussions of black church leadership, and consequently their pietistic and personal theology did not immediately influence reform movements. ${ }^{9}$

A proper study of church denominations necessarily contextualizes and historicizes the field. The starting point for these denominations begins with the birth of the American Republic. After the American Revolution, the national disavowal of any formal church-state bond, and the similar state-level dissolutions thereafter, allowed for an implicit pluralism among religious bodies. No single church was privileged, resulting in a multiplication of competing sects and organizations. ${ }^{10}$ These organizations varied on local, regional, and national levels. They diverged on theological issues, ecclesiastical organization, involvement with the public sphere, and 
political tendencies. However, as regional or national organizations, they contained divergent trends within them, as well; no single denomination encouraged a single and simple movement without alternative theological interpretations or social imperatives toward other positions.

This church history study also necessarily considers denominations as legitimizing bodies, both for the individuals within them and for the nation in which they reside. The creation of black denominations in the antebellum era implied some level of Americanization for these groups, a willingness to work within the system rather than overturn it. ${ }^{11}$ Denominations necessarily employed bureaucratic rather than charismatic organizational forms; although their spiritual leaders may have also appealed to noninstitutional authority, denominations also instituted forms that paralleled those in white churches. Thus, black churches employed a dialectical, rather than oppositional, relationship with white American Protestantism. ${ }^{12}$ In fact, the first two groups, Episcopalians and Presbyterians, were, properly speaking, not black churches in the sense that they were part of larger, white-dominated and controlled bodies. ${ }^{13}$

\section{Episcopalians}

Both Episcopalians and Presbyterians were part of what might be deemed formalist denominations, those with well-established connections to civil authorities. ${ }^{14}$ The Church of England created the first black missions in the British Atlantic world, and thus provided the foundation for the first black church in Anglo America. As an established church, the Anglican Church was intricately connected with the British government, and thus claimed a unique right toward spiritual and temporal authority; its leading members were also leading representatives of government and finance in their communities. Also, as representatives of the established church, churchmen held that they owed a missionizing duty to all the empire's subjects, including black slaves and Native American tribes. These tendencies toward clerical authority, social prestige, and universal mission remained even after the American Revolution destroyed the formal religious establishment of the Anglican Church in America. In the transformed postrevolutionary religious environment, Anglicans became Episcopalians, and the Church of England, the Protestant Episcopal Church, one denomination among many. ${ }^{15}$ 
The Protestant Episcopal Church's theological and institutional imperatives intertwined; theologically, the Protestant Episcopal Church in America retained the roots of religious establishment, even though it was no longer formally connected to the state. The dominant theological leadership in the United States identified with the High Church Party, which held that the denomination possessed spiritual primacy and significance because of the Episcopalian ecclesiastical line of bishops; the principle of apostolic succession held that Episcopal bishops extended in an unbroken line back to Christ, and to Peter as head of the Church. ${ }^{16}$ Such a stance led to a position of moral authority, a right to claim significance by means other than democratic vote and superior numbers.

Institutionally, Episcopal ecclesiology or church organization retained a hierarchical structure. Only the presence of authorized, ordained clergy rendered a worship service legitimate; such clergy ranked, lower to higher, from liturgical worship leaders, to deacons, priests, and vicars, to bishops and archbishops. Just as every lower-ordered cleric submitted to the orders above, so did each individual congregation, or parish, remain a subservient part of the larger diocese and church as a whole. The Episcopalian denomination's centralized organization emphasized church unity and obedience. Schism was nearly unthinkable, despite factional disagreements over theological or political issues. Alone among the large Protestant denominations, the Episcopal Church did not divide into northern and southern wings in the decades before the Civil War. ${ }^{17}$

The Episcopal Church's spiritual authority was embodied in formal structures of worship. Services were liturgically based, relying on standard readings and orders of worship. The high-toned liturgy included a literary and formal use of the English language through the Book of Common Prayer, and adherence to traditionally composed hymnals. Worship leaders read prayers directly from the Book of Common Prayer; extemporaneous or inspirational expressions in prayer or preaching were generally discouraged. ${ }^{18}$

The Episcopal Church contained hundreds of black worshipers, some whose ancestors' church roots began in colonialera missionary efforts. Few were part of a black church, strictly speaking, as they represented individual believers within larger white-dominated congregations. However, the few black Episcopalians who were part of the black church were disproportionately significant in their range and influence. Two congregations, specifically, represented an Episcopalian version of 
the black church in antebellum America. In Philadelphia, St. Thomas African Episcopal Church formed alongside Richard Allen's more well-known Bethel African Methodist Church in the 1790s. And in New York City, St. Philip's African Episcopal Church formed a little more than a decade after black Methodists organized in that city. After these two, black Episcopal churches would form as St. James in Baltimore, St. Luke's in New Haven, and Christ Church in Providence, Rhode Island, and from thence to other towns in the North. ${ }^{19}$

As befitted the Anglican standards of training and ordination, men who attained the highest levels of education to become ministers showed an extremely high level of quality in their writing. Peter Williams, first rector at St. Philip's in New York, evinced a solid command of English. A youthful presentation commemorating the end of the slave trade, presented before he had ascended to the ministry, gained wide praise for its beauty and poise; in it, Williams contrasted the Eden-like state of Africa with the barbarous practices of slave traders. In later letters, such as the one Williams offered to explain his family's patriotism and defend himself from charges of radicalism, he displayed a similar balance and clarity. These writings from Williams were not offered from the pulpit, but in an outside capacity as a public citizen. ${ }^{20}$

William Douglass, pastor at St. Thomas in Philadelphia, published a series of sermons two decades after Peter Williams's death that showed both attractive literary qualities, and a reticence to make any political statement. Balanced and lyrical, Douglass's writing compares favorably to the antebellum sermons of any pastor in any denomination. Each homily unpacks a central theme; connects to biblical verses; and exhorts Christians hearing the message to avoid sin, seek forgiveness, and pursue justice. Strikingly, however, none provide any sense of the author's race, or of any political statement on the day, as befits a minister from a denomination doggedly insistent on avoiding public controversy. ${ }^{21}$

The social makeup of black Episcopalians suggests they shared connections to the forms of hierarchy and formal worship that the Episcopal Church emphasized. At both St. Thomas and St. Philip's, the members were likely to have roots in the city as native-born Pennsylvanians or New Yorkers, respectively. Economically they tended to be the elite within the black community. Many parishioners worked in service positions where they amassed great wealth, such as restaurateur George T. Downing of New York or clothier Joshua Brown in Philadelphia; others were among the first in professions that were generally barred to blacks, such as doctor 
James McCune Smith in New York. Many had white patrons who helped them advance occupationally, such as St. Philip's Peter Ray, whose connections to the Episcopalian Lorillard family was not merely spiritual but also temporal: Ray worked as a supervisor within the Lorillard tobacco factories. ${ }^{22}$

The literary emphasis on Anglican forms of worship influenced the types of reform black Episcopalians championed, which were uniquely centered on education and the liberal arts. Black Episcopalians were among the first and most consistent voices to promote literary and scientific societies. They were among the first to promote education and black schools. ${ }^{23}$ John Peterson and John T. Zuille were members of St. Philip's and leading black educators; both took part in literary societies such as the Phoenix Society, organized by rector Peter Williams Jr. Members of St. Thomas, including William D. Forten, John P. Burr, and Benjamin Stanley, supported the Demosthenian Society and Banneker Institutes in Philadelphia, both of which emphasized liberal arts in debate and culture. $^{24}$

Alongside education, black Episcopalians were quick to support temperance and moral reform initiatives, to emphasize blacks' individual responsibilities. St. Thomas's parishioners dominated the rolls of the American Moral Reform Association, which emphasized self-help and personal morality. The society received some criticism from blacks who felt it was too abstract in its aims, but the emphasis on personal improvement matched the generally high educational aspirations of the Episcopalian path. Similar aims were found in New York's Phoenix Society, founded by St. Philip's rector Peter Williams, Jr., and frequented by black Episcopalians such as Henry Williams and John Peterson, among others. $^{25}$

Black Episcopalians targeted reforms that emphasized protecting individual rights, the same freedoms that they employed in promoting literary pursuits and moral improvement. Black Episcopalians such as William Lambert and Henry Williams were leaders in northern vigilance committees, which protected free blacks and runaway slaves from southern kidnappers. Others, such as Frederick Hinton, supported voting initiatives, which used petition and persuasion to attempt to expand black franchise. Individual black Episcopalians wielded personal wealth and influence to participate in such committees. ${ }^{26}$

Although many black Episcopalian laity took leading roles in their respective black communities, their clergy were forced to remain silent in the public sphere. Bishops and governing counsels 
emphasized ecclesiastical unity, and especially pushed clergy toward quietism and noninvolvement in political or reform issues. The original black rectors of St. Thomas and St. Philip's, Absalom Jones and Peter Williams, respectively, came from Methodist backgrounds and chafed at such restrictions. Both men took part in interdenominational displays of black unity and calls for reform. They faced opposition for doing so, however. In the case of St. Philip's, New York Bishop Benjamin Onderdonk forced Williams to resign from an official position in the American Anti-Slavery Society after antiabolitionist riots destroyed Williams's church in $1834 .^{27}$

As part of a denomination numerically dominated by whites, black Episcopal congregations could expect to be led by white ministers, sometimes for decades, when their black priests died or moved away. ${ }^{28}$ This was connected to denominational organization and theological demands that clergy have high levels of education and training, and formal ordination at the hands of their ecclesiastical superiors. That imperative, however, could lead churches to suffer at the hands of white leadership indifferent to their needs, as St. Philip's did for several decades when white leaders refused it diocesan representation. Black priests were generally forced to be silent on social issues, and black Episcopal congregations as such also rarely spoke out on political issues. Individual laity did express political ideals, but in the church, black Episcopalians followed larger church practice in abstaining from the major issues of the day. ${ }^{29}$

This did not mean that individual black Episcopalians stayed silent on any given issue. The stresses of remaining within a white-run denomination that did not value them honed the sensitivities of some black Episcopalians toward a clear understanding of their own identity, and a tough-minded vision of the sacrifices required. Episcopalian James McCune Smith became an accomplished medical doctor, the first black in the United States to do so. Perhaps because he felt the second-class status within his white-run denomination, Smith ardently defended the position that blacks needed to create reform and antislavery institutions separate from whites. He rejected John Brown's raid on Harper's Ferry not for its radicalism, but for its interracial moderation: He thought blacks did not need, and should not take, white aid to fight for their freedom. McCune and other black Episcopalians, who did not compromise in demanding literacy and high cultural standards for themselves, nonetheless rejected white suggestions that they use their culture to reform Africa: Such laity were on the front lines in 
opposing colonization efforts in favor of building communities within the United States. ${ }^{30}$

Such tenacity could extend even to Episcopal clergy, albeit in different forms. As a formerly established church, the Episcopal Church held universal aspirations that reached invisible lines of influence across the Atlantic and around the world. The big aims embedded in Episcopal Church structure and missions eventually helped influence blacks who would promote forms of black nationalism. When Alexander Crummell, for example, became an Episcopal priest, he chose not to submit to the authority of white leaders who repeatedly denied him ordination. Instead Crummell ministered to blacks in Liberia for over two decades. Unbowed, he clung simultaneously to Anglo cultural ideals as well as the idea of black unity, even a black nation, across existing political lines. His Episcopalian training helped him achieve this combination, and led other clergy such as Augustus W. Hanson, William Lambert, and James T. Holly to support such efforts. W. E. B. Du Bois singled out Crummell for praise in his groundbreaking work, Souls of Black Folk, for the latter's unflinching support of both political and cultural attainments. ${ }^{31}$

The black Episcopalian experience highlights the complexity, mixed motives, and contradictory impulses that denominational affiliation created. Blacks raised in the Episcopal church would be influenced by that church's emphasis on hierarchy and literacy. They depended on whites as patrons, and, given white control of the church hierarchy, faced barriers to religious advancement. Exposure to white racism, however, despite impressive cultural achievements, would lead some black Episcopalians to uncompromising reformist positions; further, Episcopalian universalizing aims could nurture an early form of black nationalism and internationalism, which reached across existing political boundaries.

\section{Calvinists}

The second strain of the antebellum black church consists of the denominational groups of black Presbyterians and black Congregationalists, united in part by a common theology. Some of the first blacks who converted in colonial-era revivals belonged to this tradition, including such famous names as Gustavus Vassa (Olaudah Equiano) and Phillis Wheatley. In the antebellum era, these churches grew more numerous than the black Episcopalian group, although they were a fraction of the number of black Methodists and 
Baptists: Twenty to thirty black Presbyterian and Congregational bodies worshipped at the time of the Civil War. Like the Episcopalians, however, they remained under larger, white-controlled religious bodies. ${ }^{32}$

Theologically the Presbyterian-Congregationalist strain in America was Calvinist. Although a complex and varied system, one common feature of Calvinism emphasized the sovereignty of God. God was a lawgiver and judge, and God's moral laws of nature, as well as just laws given by society's leaders, were to be obeyed. Absolutely just, morally perfect, and all-powerful, the Calvinist God demanded punishment for sin. This insistence could cut in different ways: The universal reality of sin meant all humans, black and white, shared a common nature and a common need to seek God's justice, which led to an insistence on the importance of following God's higher laws, over those flawed laws created by man. Other Calvinists, recognizing sin as limiting human action, fought against what they saw as the hubris of moral crusaders, who often ignored church order and sound theology in pursuing their higher aims. ${ }^{33}$

Calvinism insisted on the centrality of the scriptures; Bible reading lay at the heart of individual devotions, and preachers' exposition of scriptural passages organized community worship. Proper biblical preaching required a clergy fully trained in a university-level education as well as theology, and many recognized that training should be accessible to potential black pastors, too: Of the five colleges James McCune Smith identified as being friendly to educating blacks, all had ties to the Presbyterian Church. Although some Calvinist groups privileged revivals that focused on heartfelt conversions, in general ministers' extensive training in complicated theology led to messages that outside observers described as logical, rigorous, and abstract, even philosophical. ${ }^{34}$

Although Presbyterians and Congregationalists differed institutionally, they shared an emphasis on order and social prestige. The Presbyterian Church, which was numerically strong in the Middle Atlantic and Southern states, employed a hierarchy similar in kind (but not in degree) to Episcopalians; larger conferences (Synods or Presbyteries) oversaw local levels of church governance. In contrast, Congregationalist polity was decentralized, organized around local congregations. However, Congregationalists carried with them remnants of religious establishment in New England, where their numerical base remained strongest. ${ }^{35}$ Unlike the Anglicans, whose establishment the Revolution destroyed, Congregationalism remained formally connected to the state for many years (until 1818 in Connecticut and 1835 in Massachusetts), 
and informally through social prestige and connections for far longer. ${ }^{36}$ Socially, both groups tended to attract society's elites, if not quite at the level of the Episcopalians, than certainly those higher in the social strata than the typical Methodist or Baptist. ${ }^{37}$

The Presbyterian and Congregational emphasis on the scriptures led to a corresponding value on literacy. The first black literature published in the English language came out of this tradition, during the Revolutionary era. James Albert, Gustavus Vassa, John Stuart, Phillis Wheatley, David George, and John Marrant all identified with Calvinist religious groups, and published accounts ranging from poetry to conversion narratives to political sermons. After the war, black clergy, whose literacy and education encouraged forays into religiopolitical discourse, began to publish. John Marrant, who traveled widely, published sermons that supported an idea of transatlantic black nationalism. Lemuel Haynes (1755-1833), a long-time Congregationalist minister in Vermont, harmonized Calvinist theology with American republicanism to argue that slavery imperiled the American experiment with liberty. By the end of Haynes's life, Presbyterian minister Samuel Cornish had published the first black periodicals, Freedom's Journal and the Colored American, the latter helped by younger minister Charles B. Ray. By the 1840s and 1850s, James W. C. Pennington authored a textbook that challenged racist assumptions about the origins of blacks, and penned an account of his early life in slavery. ${ }^{38}$

Like the black Episcopalian group, black Calvinists supported reform movements that furthered the aims of literacy and moral instruction. This included Sunday Schools, which were supported by Presbyterians Thomas Van Rensselaer and Stephen H. Gloucester; and temperance societies that gained support from Presbyterians James Pennington, Charles Ray, and Theodore Wright, as well as Congregationalist Amos Beman. One Presbyterian, John F. Cook, also attacked tobacco, partly for its moral stain, and partly because purchasing tobacco patronized the slave systems that grew it. In New York, the literary and moral reform-based Phoenix Society met in a Congregational church, and drew support from Presbyterians such as Theodore Wright, who also helped form an associated high school. $^{39}$

Whereas Episcopalian theology and ecclesiastical structure tended to handcuff ministers' actions in the public sphere, the Presbyterian-Congregational model encouraged clerical action. In particular, the pastorate of First Colored Presbyterian, or Shiloh, Church in New York City hosted a line of activist ministers, starting with Samuel Cornish and continuing with Theodore Wright, James 
Pennington, and Henry Highland Garnet. Ministers Pennington and Garnet published their sermons, drawing explicitly political connections in their religious discourses. ${ }^{40}$

The biblicism of black Calvinists could have radical implications. In New England, the base of Massachusetts's law in Old Testament legal codes allowed blacks to successfully challenge the legal strictures of slavery; alone among the first American states, Massachusetts eliminated slavery by judicial fiat in 1783, in part because of the Calvinist religious underpinnings of its legal code and heritage. The adherence to a strict sense of biblical justice in the service of an all-powerful God could also have electrifying ramifications for black Calvinist leaders. Congregationalists and Presbyterians had historically supported revolt against authorities they deemed unjust or unscriptural. Henry Highland Garnet, for example, forthrightly and unapologetically announced that slaves had a moral right to revolt, a position that many of his fellow reformers retreated from in the 1840s. ${ }^{41}$

At the same time, even as Episcopalian mandates were not uniformly pacifying for black leaders, neither were Calvinist traditions uniformly radical. The popular minister John Chavis was a prominent black Presbyterian in North Carolina who preached until legislation barred blacks from the pulpit in 1831. Echoing the earlier poems of Phillis Wheatley, Chavis opposed immediatism and preached that the institution of slavery provided the means for the conversion of blacks to Christianity. Black Presbyterian ministers such as Philadelphia's Charles W. Gardner were sometimes dogged by black reformers with charges of acquiescence to slaveholders, and Philadelphia Presbyterian Stephen H. Gloucester turned "cautious, defensive, and accommodating" when a mob destroyed his congregation in 1842, as he criticized abolitionist groups for their extremism. Further, because Congregationalist and Presbyterian bodies remained biracial, whites controlled their organization, and sometimes attempted to silence political action. White ministers criticized Samuel Ringgold Ward and Henry Highland Garnet, in particular, for preaching politics from the pulpit. ${ }^{42}$

Finally, although theology could encourage black churchmen to support radical positions, that same theology divided them from other reformers. Black Calvinists' insistence on biblicism and theological orthodoxy led most of them to break with William Lloyd Garrison's American Anti-Slavery Society in 1840 for Garrison's heterodox anticlericalism and support of women's rights. Instead they backed the American and Foreign Anti-Slavery Society, which, 
despite their initial support, ineffectively limped along throughout the 1840s, weakening the abolitionist cause. ${ }^{43}$

Biracial congregational and denominational models, in worship and institutional organization, connected black Episcopalians and Calvinists. ${ }^{44}$ Both groups shared an insistence on formal organization and ordained clergy, and individuals within generally remained loyal to these larger institutions. Black Episcopalian and Presbyterian congregations alike had periods during which they were served by white clergy, who had varying degrees of sympathy for their positions, but their loyalty to denomination entailed that they remain Episcopalians, Presbyterians, or Congregationalists rather than move to black-run institutions. ${ }^{45}$

Forms of cultural elitism as expressed in literacy and moral purity, and a willingness to use the power of the church and state to coerce reforms, also united black Episcopalians and Calvinists. Both groups took a dominant role in the formal reform communities, ranging from moral elevation, to temperance, to antislavery. The dominant language, or discourse, of antebellum black reformers employed the concept of uplift. Uplift ideology suggested that free blacks needed to pursue moral, intellectual, cultural, and economic improvement on a personal and communal level, and in so doing, would force whites to recognize their achievements and consequently grant them greater political rights and economic opportunities. As Samuel Cornish put it in the pages of Freedom's Journal, the first black-run periodical in the United States, the onus was on free blacks "to convince the world by uniform propriety of conduct, industry, and economy, that we are worthy of esteem and patronage." 46

This emphasis on moral suasion and cultural development strikes many modern listeners as ineffective on the one hand, and elitist on the other. At the time, however, the Episcopalian and Calvinist social backgrounds of many of the leading reformers meant that the language of uplift resonated with them. Both groups' connections to white bodies, too, allowed uplift to make sense, as the concept employed the same presuppositions that white Americans at large thought were necessary for the creation of a successful life on the individual level, and a successful society communally.

\section{Methodists}

The third group, black Methodists, was the first group that might be considered part of the black church proper, as the African 
Methodist denominations began separation from white-run bodies starting in the 1790s. Although Methodism as a formal body reached out to blacks later than Episcopalians or Calvinists, in part due to that group's late start in the North American colonies, it was the first to achieve a black religious identity, forming separate bodies before the other two. Further, black Methodist groups were among the first to take the name African, creating a national identity as a point of resistance that blacks in America would embrace for more than a generation. $^{47}$

Theologically, Methodism promoted a greater emphasis on the individual believer than either the Episcopalians or Presbyterians. The title Methodist derived from an initially derogatory term directed at the group's founder, John Wesley, in that believers worked disciplinary "methods" to progressively move toward salvation. The individual believer employed prayer, scriptural study, almsgiving, good works, and worship in a community of believers to accompany the faith in Christ that brought salvation. Methodist theology was much more blunt and straightforward than the Episcopalian or Calvinist models, insisting that a common-sense understanding of the scriptures was sufficient to receive the full gospel. In the early Republic, Methodists were known for their enthusiasm in worship, with emotional responses to fervent preaching. They also were far more populist in their composition, being known largely as a working-man's church; most preachers started as laymen, and lay preachers remained central to the life of the local congregation. ${ }^{48}$

Institutionally, however, Methodists, both black and white, incorporated a central administrative system, which led ultimately to bishops or superintendents at the top of a church hierarchy. Because their numbers were far greater, the networks of African Methodism were necessarily far more extensive and bureaucratically intertwined than the few examples of black Episcopal congregations or the regional networks of black Calvinists. Consequently, over time, the African Methodist church included greater formalism and hierarchy. ${ }^{49}$

As a far larger movement than the blacks who worshiped within white bodies, and as a movement that privileged individual experience, African Methodism was Janus-faced and included within itself multiple, sometimes even contradictory, trajectories. ${ }^{50}$ The enthusiasm in worship and emphasis on individual, heartfelt conversion provided a leveling experience that led to democratic impulses within the church; Methodists prized the "poor and lowly" among them who accepted the gospel message. Initially, black exhorters preached in mixed-race settings, with the support of white church leaders. Women wielded considerable spiritual authority, and 
in some settings, exhorted to mixed groups and led worship services. Black women, particularly, appear regularly in early Methodist history as important participants. Betty, a black slave woman, was one of the first Methodists to meet in New York's first meeting. Jane Barsary, an enslaved woman, led a class meeting of blacks in 1780s New York City, a position that no white women held there. Later, women such as Jarena Lee and Sojourner Truth felt called to preach the gospel message and traveled to camp meetings to share their testimony with other Methodists. In their examples, the black church contained a strong feminine component. ${ }^{51}$

The institutional formalism of Methodism pushed against some of these democratic impulses. A number of leading clergy such as Richard Allen and Christopher Rush disagreed with the desire of black Methodist women to take part in the formal ministry of the church. Charismatic woman preacher Jarena Lee struggled to reconcile herself to Allen's opposition. Ultimately, Lee's individual, spirit-commanded imperative to preach caused her to break with Allen and pursue her own ministry. A similar dynamic occurred for Sojourner Truth, who attempted to minister to other women in the African Methodist Church in New York, but left weeping when she was rebuffed by women who favored male ministers. ${ }^{52}$

Male clergy among the African Methodists appear at times to have fully embraced the model of elite uplift that black Episcopalian and Calvinist reformers promoted. The leader of black Methodism, Richard Allen, was suspicious of overenthusiastic forms of religion. Others followed his lead. Methodist minister and bishop Daniel Payne was a forceful advocate for an educated clergy, as well as genteel forms of worship. In this, black Methodists paralleled a path white Methodists also took, for the white bodies also moved from greater charismatic authority toward more bureaucratized forms of organization. $^{53}$

As a whole, however, black Methodists' emphasis on formal training and uplift was of a different model than that of the Episcopalians and Calvinists. As a results-oriented theology, Methodism was focused on the material more than the cultural. Richard Allen, for example, embodied uplift, but achieved it through manual labor; he purchased his own freedom through hard work, and undertook a number of manufactory and merchandising businesses in his life, even as he remained a minister of the gospel. Methodist uplift did not focus on literary or philosophical education in itself. Literacy was important as a means to an end, primarily through the reading of scripture; literacy for its own sake was more likely a provenance of Episcopalians and Presbyterians. In fact, the 
strongest black Methodist voice for educational and cultural attainment, Daniel Payne, began his career in a CongregationalPresbyterian pastorate; Payne encountered resistance at his attempts to elevate and add culture to Methodist worship services, and was often in the minority in these efforts. ${ }^{54}$

The African Methodist book of doctrine and discipline, which Richard Allen wrote, exemplifies this practical bent. In the discipline, a series of Socratic questions and answers followed the initial statement of faith. In the section advocating that ministers make regular home visits to members, an objection is raised that such visits would take time from one's studies. The reply, in four parts, emphasizes salvation over all study and learning:

1. Gaining knowledge is a good thing, but saving souls is better. 2. By this very thing you will gain the most excellent knowledge, that of God and eternity. 3. You will have time for gaining other knowledge too. Only sleep not more than you need: "and never be idle or triflingly employed." But 4. If you can do but one, let your studies alone. We ought to throw by all the libraries in the world, rather than be guilty of the loss of one soul.

Similarly, on preaching, both Richard Allen's Bethelite Methodists and the New York-based Zionite Methodists advocated that preachers focus on Christ, and choose the plainest text to do so; such emphasis differed from both black Episcopalian and Calvinist approaches. ${ }^{55}$

Although a few black Episcopalians and Calvinists considered revolt for slaves, Methodist action could be more blunt. Black Methodist David Ruggles was active in vigilance committees that strove to protect free blacks and runaway slaves from capture. Ruggles abandoned nonresistance to forcefully advocate blacks' rights to fight off attackers and kidnappers. His end goal was so important to him that Ruggles sometimes ignored the means to reach it. In one case, his desire to publicize a suspected case of manstealing led to a lawsuit that bankrupted the Colored American newspaper. Presbyterian Samuel Cornish, more formally inclined, did not forgive Ruggles for this rashness. In one prominent example, black Methodism directly influenced rebellion. Denmark Vesey's conspiracy in Charleston, South Carolina, in 1822 originated in that city's African Methodist Church. Whereas individual Episcopalian laity could support revolt in the abstract, and Presbyterian clergy preached the ideal of it, some Methodists went forward with a plan of attack. ${ }^{56}$ 
The interconnectedness of Methodist districts did create a national scope for the institution. Initially, the first black leaders in Northern cities who promoted reform and antislavery measures were Methodist. These included Richard Allen in Philadelphia and James Varick in New York; even those Episcopalian priests who led in reform matters, Absalom Jones in Philadelphia and Peter Williams Jr. in New York, had grown up in Methodist settings. As separate, black-run denominations, African Methodist groups could be less circumspect on the issue of slavery: Both Bethelite (Philadelphia) and Zionite (New York) black Methodists ruled that slaveholding was not permitted for any member within their denominations, a position black Episcopalians and Presbyterians, outnumbered in larger white bodies, could not insist upon. ${ }^{57}$

However, the institutional growth and success of African Methodists ironically led to their retreat on reform matters, for a time. Local congregations in the Upper South and in border states could suffer white attacks from a too-ardent antislavery position, so African Methodist denominations tended to pull back from outright statements of abolition. The growth of the institution also led to its own internal self-preservation, whereby ministers focused on their own advancement, and the church's upkeep, over outside matters. Methodist emphasis on simplicity sometimes led to a focus on the preaching of the gospel as paramount; believers' focus on becoming holy trumped other causes. Reform movements sometimes served as vehicles for individual sanctification-that is, temperance movements were not there to uplift the race or to reform society, but to allow the individual believer to shun the sin of drink. ${ }^{58}$

The black-run and black-led status of African Methodism was not without controversy. Although a member of an African Methodist Church, Frederick Douglass critiqued black-run churches for, at times, being too comfortable in their sheltered environments. Black separation, wrote Douglass, allowed whites to forget blacks too easily, and could lead to complacency in matters that required effort and risk. Black Methodist ministers could be and were charged with colluding with slaveholders or compromising their messages of liberty. ${ }^{59}$

However, the Methodist emphasis on self-governance represented an important step in the development of black religious community. Abstract ideals of black nationalism that emerged in Alexander Crummell's writings, for example, gave way to real black governance, in institutions that spanned the continent and even extended overseas. True to its practical bent, black Methodism offered a real, hands-on working out of how to organize, run, and 
lead an institution that merged spiritual aims with life in the material world.

\section{Baptists}

The final strain of antebellum black Christianity, that of the Baptists, included a number of groups whose sheer diversity belies any attempt to put a singular label on them. Initially, in the American colonies, the term Baptist referred to a branch of Calvinist Congregationalists who rejected the sacrament of infant baptism, instead requiring adult baptism as a sign of repentance and forgiveness of sins. After the Revolution, Baptists represented a large and diverse body of believers like the Methodists, but without that latter group's institutional scaffolding. Baptist experience varied by location and centered on the local community of believers, not its national or international affiliation. ${ }^{60}$ Consequently, any discussion of Baptist theology must offer careful caveats about the setting, time, and place of the group analyzed. That very care, however, makes an important point about structure: The local basis of the church meant local autonomy of that church, to a far greater degree than any other group.

As with Methodism, Baptist theology tended to emphasize the importance of the individual, particularly the necessity of each individual to achieve a conversion experience, a felt sense of divine grace, that would offer proof of salvation. The particular dynamics of that experience could vary considerably. Baptists fell into General (Arminian) and Particular (Calvinist) camps, although most blacks during the nineteenth century tended to fit the former category. For all Baptists, evidence of ethical action was essential. This moral focus on pious behavior often defined Baptists, both in their own local setting and against other religious groups. More than any other group, however, Baptist theology tended to be less corporate and more individual, or, more precisely, more applicable to the individual setting of the believer and the congregation rather than the larger society as a whole. Consequently, Baptists were less likely to offer support for group action or social reform, beyond those movements, such as temperance, that helped shepherd individual believers toward right action on a personal (or, at most, congregational) rather than national level. ${ }^{61}$

In northern settings, especially in New England, Baptists grew out of Congregationalism. Consequently, northern black Baptists tended to be Particular (or Calvinist), and often moved from 
Congregational to Baptist churches, and back, depending on local circumstances. Such black Baptists functioned in many ways much like Congregationalist blacks, with the exception that they worked within primarily black, rather than white, institutions compared with their Congregational brethren. ${ }^{62}$

Farther south, however, the variety of Baptist organizations, as well as the local imperative to resist any change from outside or national forces, could spell major differences in the range of religious beliefs and practices. In some cases, the Particular Calvinism that defined colonial-era Baptists remained in a few pockets of black religious activity. David George, for example, converted in the Deep South and joined one of the first black Baptist churches in the colonies, but retained Calvinist precepts to the point that he disgusted the Arminian-inclined British evangelical governor in Sierra Leone, Zachary Macaulay. ${ }^{63}$

Demographically, however, the comparatively large and increasing numbers of blacks in the South meant that the black Baptist faith there acquired a flavor very different from anywhere else on the English-speaking mainland. Scholars such as Mechal Sobel have uncovered powerful connections between West African culture and southern black Baptist faith. African cosmology, including forms of ancestor reverence, imbued Baptist thinking and belief. Baptist conversion narratives and reliance on faith healing paralleled West African beliefs in spirit possession. The invocation of heaven in ecstatic ceremonies borrowed from African conceptions of nonlinear time. And the submersion of the believer in the waters of baptism invoked West African beliefs that found spirits to reside in water. $^{64}$

At the same time, such Southern, black, Baptist churches began to organize around forms that white evangelicals would recognize. The populist (or at least popular) messages from the pulpit reached out to common believers in ways that social elites, including some clergy, found uncouth. Baptist ministers often gained authority from their charismatic and extemporaneous deliveries, and, as such, operated on a vastly different pole in comparison with their Episcopalian and Congregational brethren in kind, and from their Methodist brethren in degree. Faith and spiritual power, not learning, mattered most. ${ }^{65}$

Institutionally, Baptist decentralization ensured that churches followed local, not national or international, imperatives. This resulted in the closest recorded relationships between whites and blacks in religious settings. Whereas black members of other churches generally faced postures of domination from their white coreligionists, with the end result often being segregated worship 
and separate institutions, in the South, white and black Baptists remained in close contact, even through the antebellum era. Some local groups remained interracial, to the consternation of elites who had hoped lower-ordered whites would be better disposed toward racial solidarity. White Baptist ministers regularly officiated at all-black or nearly all-black churches, and often moved from church to church without regard to color. When groups did segregate and blacks worshiped separately, congregations of black Baptists affiliated with white-run bodies on a regional level. They reported disciplinary proceedings to whites and often received advice on church procedure from them. ${ }^{66}$

This racial closeness could cut in different ways. Black Baptists affiliated with southern whites from necessity and from sincere affirmations of spiritual equality before Christ, but they nonetheless functioned in a world organized according to racial hierarchy. Such white contact required greater obedience and quietism on matters of reform. Preacher Hiram Revels, who later became a U.S. senator in Reconstruction-era Mississippi, noted the tightrope he had to walk, stating:

I sedulously refrained from doing anything that would incite the slaves to run away from their masters. It being understood that my object was to preach the gospel to them, and improve their moral and spiritual condition, even slave holders were tolerant toward me.

Black Baptist church records include cases where church authorities demanded runaway slaves return to their masters, and demanded strict moral codes that condemned theft and sexual improprieties. ${ }^{67}$

On the other hand, the close contact continually affirmed the Baptist support of charismatic forms of authority, of the power of the Holy Spirit to transcend earthly codes within the limits of sacred space. Multiple stories exist in Baptist circles of slaves leading masters to faith, and into the ministry. Samuel Templeman, of Westmoreland County, planned to whip his slave Cupid for singing hymns and insolently (from Templeman's perspective) worrying about the state of his master's soul, but the slave's fearless exhortations led Templeman to tears, conversion, and the ministry. Similarly, Addison M. Lewis, raised Episcopalian, would only be comforted by a Baptist slave named Morgan as he feared eternal damnation, and his trips to Morgan's cabin led to baptism and service. Historian Albert Raboteau provided the example of the slave Morte, whose ecstatic trances, which his master witnessed in the 
fields, led the master to have Morte preach to the entire plantation household. ${ }^{68}$

In the North, such racial interaction did not occur to the same degree. However, northern black Baptists' institutional autonomy also granted their churches unique characteristics. Baptist congregationalism ensured local, rather than regional or national, action, which provided a corresponding nimbleness of activity. Among New England blacks, who enjoyed the greatest degree of civil rights in the United States, Baptists were among the first and most forceful advocates of immediate abolitionism. Whereas most other black clergy and black laity rejected the theological heterodoxy of Garrisonian abolitionism in 1840, black Baptists often remained connected to Garrison. The Baptist insistence on local autonomy allowed its members to coexist with those of questionable religious persuasion in larger undertakings. ${ }^{69}$

Outside of New England, however, Baptist activity could tend toward political neutrality or quietism. The Baptist emphasis on personal morality, congregational piety, and social obedience tended to silence many black Baptists on issues of slavery and reform, at least insofar as they appear in the public sphere or written record. As one traveled farther South, such quietism allowed groups to grow and flourish, as their ability to camouflage themselves in the localized culture may have allowed them to escape some of the criticism leveled at the more-organized Methodists. Further, the decentralized organization allowed such groups to generally not depend on whites for funds. Whereas the other three main branches of antebellum black Protestantism required a trained clergy, ideally with full-time salaries, Baptists often settled for charismatic lay preachers, humble farmers and mechanics, some of them illiterate. All had the right to preach the gospel, provided they displayed suitable evidence of the Holy Spirit.

The flowering of small churches led by a self-supporting ministry of those skilled in other trades would allow the Baptists greater success in the decades after the Civil War. Such institutional flexibility, and emphasis on charismatic rather than bureaucratic authority, foreshadowed the incredible success of the Pentecostal movement in the twentieth century. In time, such numerical success would transfer to political success; twentieth-century leadership in the black community often began with the Baptists, no longer as quiet as their ancestors had been in regard to social justice. ${ }^{71}$ 


\section{Conclusion}

Critics of the black church as a conceptual model have offered valuable critiques against a too-simple understanding of the black church. These scholars have successfully noted that the black church as an institution could be exclusive, discriminatory, or acquiescent toward racism. Such criticisms provide a useful corrective to insider church histories that have traditionally tended toward triumphalism. ${ }^{72}$

This study's attempt to consider multiple black religious traditions mutes the harshest of these criticisms. First, it provides necessary historicity to avoid overessentialism toward definitions of what is black, or what is the church. ${ }^{73}$ Over time, and in different times and places, black Americans created religious experience while in contact with preexisting religious traditions, resulting in a range of activities and stances. There was no single black church but a number of black churches-I posit four large groupings here, but many more could be suggested-each with its own theological tradition, ecclesiastical structure, and relationship with white bodies. Religious affiliations created real distinctions within the black community.

This consideration also broadens previous conceptions of the black church. Blacks who worshipped together in larger, white-run institutions, such as Episcopalians, or black clergymen who ministered to mixed-race or white congregations, such as Lemuel Haynes, remained in conversation with each other and with other black religionists, and as such provide key counterpoints to tooeasy assumptions about what black religion looked like. Black churchgoers in white institutions felt greater coercion and could not act freely, but in some instances their choices to remain affiliated with those groups offered strengths that those in larger independent black churches did not always share.

This approach offers greater historicity to understanding the black church. These four groups emerged at different times, reflecting their different sources of support. White missions to blacks began with Anglican missions and continued with Presbyterian groups, then Baptists, and finally Methodists. Yet black churchbuilding, the act of gathering and separating as distinct bodies, occurred in a nearly opposite order: Black Baptists began worship in the South with the first evangelical revivals before the Revolution, and black Methodists emerged when Wesleyan Methodism crossed the Atlantic during the Revolution. Black Episcopalians started a bit earlier than black Presbyterians, albeit in limited settings, but both groups, as black churches, began later and grew slower. 
These four groups were also highly unequal in numerical composition. The number of black Episcopalian churches before the Civil War can be counted on one hand. There may have been as many black Presbyterians and Congregationalists in all the United States as black Methodists in Philadelphia alone. And, although the number of Baptists is impossible to fully determine, anecdotal evidence of huge numbers of black members attending gatherings from Virginia to the Carolinas suggests that grouping would outstrip all the others, even Methodists, combined. Perhaps in part because African Methodist and black Baptists built their ecclesiastical structures with clear racial identification and few explicit connections with white bodies, rank-and-file blacks were more willing to join them. ${ }^{74}$

Although a fraction in membership, Presbyterians and Episcopalians were second to none in influence. The formalism of these denominations meant an emphasis on institutional organization. Early black organization efforts, such as the convention movement begun at the same time white abolitionists began to organize in the 1830s, therefore, owed much to the formalist training of black leaders in these denominations, even as they represented but a fraction of the larger black church attendance. Further, both religious groups' emphasis on literacy, whether for liturgical or scriptural reasons, created natural avenues into publishing, and thus into public forums for persuasion and protest. Although black Methodists and Baptists also published, they did not do so as quickly, or as often. Ultimately, black Episcopalian and Presbyterian activity, because it was connected to white-led denominations with formalist assumptions of political activity, furthered the emphasis on uplift ideology that formed the dominant strain of black reformist discourse before the Civil War.

Uplift ideology, which focused on black conduct and individual morality rather than white recognition of legal rights, owed a great deal to the formalist denominational decisions of black leaders. Some of this decision may have been institutional; black Presbyterians and Episcopalians remained part of larger, white-run bodies through the Civil War, and had to make accommodations to them. This was especially so in Episcopalian circles, where institutional hierarchy silenced impulses for reform even among white northern liberal members. Nevertheless, the formal emphasis in both these theologies on right conduct and public morality, and the connection of such denominations to social structure and hierarchy, made the leap to the ideal of uplift more likely for both groups. $^{75}$ 
Such influence was not all sanguinary, and perhaps helps explain why some scholars today remain skeptical of the uses of the black church. The influence on rational discourse and moral uplift necessarily limited the influence of prophetic or spiritual condemnations such as emanated from Baptist voices in ecstatic trances, or of women's religious leadership that took shape among minority groups of both Methodists and Baptists. The spirit-filled community prayer meetings and the women's groups that laid the foundation for a widespread bus boycott to occur in Montgomery, Alabama, in 1955, for example, are testament to the nonformalist denominational experiences of the large majority of black religious adherents. Such tendencies toward prophetic action took a back seat in antebellum discourse.

The historical methodology employed here, which includes a consideration of theological and institutional imperatives, could apply to any number of historical contexts, American or international, ancient or modern. Black historical actors have typically affiliated with and taken upon themselves a variety of religious identities. ${ }^{76}$ In a modern world in which black religious choices are numerous, and increasingly non-Christian, or even nontheistic, the ability to plot structures or ranges of possible actions within specific denominational traditions could prove particularly useful in a larger setting. In the case of the black church, theological and ecclesiastical structures helped shape, but did not absolutely determine, choices for the congregants who worshipped there.

Kyle T. Bulthuis is Associate Professor of History at Utah State University.

\section{Notes}

The author wishes to thank Albert Raboteau, Yvonne Chireau, Christopher Cameron, Jacob Dorman, and Bryn Upton for their insightful comments on earlier versions of this article.

${ }^{1}$ Richard S. Newman, Freedom's Prophet: Bishop Richard Allen, the AME Church, and the Black Founding Fathers (New York: New York University Press, 2009), 14-26, 63-68. Newman provides a comprehensive analysis of the break, including the range of Allen's possible motives and time frames that suggest a possible earlier departure. For an earlier account that, in part, attributes an early form of black liberation theology to Allen's motivations, see Carol V. R. George, Segregated Sabbaths: Richard Allen and the Emergence of Independent Black Churches, 1760-1840 (New York: Oxford University Press, 1973). 
${ }^{2}$ Allen briefly affiliated with the Free African Society a second time, but again departed that group to raise funds for his own Methodist church, which took the name of Bethel. See Albert J. Raboteau, "Richard Allen and the African Church Movement," in A Fire in the Bones: Reflections on African-American Religious History (Boston: Beacon Press 1995), 79-102, esp. 84-89.

${ }^{3}$ See, for example, Carol V. R. George, "Widening the Circle: The Black Church and the Abolitionist Crusade, 1830-1860," in African American Religion: Interpretive Essays in History and Culture, ed. Timothy P. Fulop and Albert J. Raboteau (New York: Taylor and Francis, 1997), 153-76. Larger religious history surveys that tend to adopt this position include Sidney E. Ahlstrom, A Religious History of the American People, 2nd ed. (New Haven, CT: Yale University Press, 2004), 710-13, 1071-76; Patrick Allitt, Religion in America since 1945 (New York: Columbia University Press, 2003), 47-51.

${ }^{4}$ Critics of the black church suggest that conceptions of the black church have privileged Protestant evangelical groups as normative, excluding the range of religious practices African Americans have joined outside such traditions. Such conceptions have further heightened essentialized conceptions of black religion as emotional and natural. They have found the church's actions to be, at times, not unified, and often not progressive. And they have suggested that the Christian orientation of church necessarily obscures the violence, cultural as well as physical, embedded in the story of the Middle Passage and conversion to Christianity. Examples of such critiques include Jawanza Eric Clark, Indigenous Black Theology: Toward an African-Centered Theology of the African American Religious Experience (New York: Palgrave Macmillan, 2010); Barbara Dianne Savage, Your Spirits Walk Beside Us: The Politics of Black Religion (Cambridge, MA: Harvard University Press, 2008); and most provocatively, Eddie Glaude, Jr., "The Black Church is Dead," Huffington Post, February 24, 2010, http://www.huffingtonpost.com/ eddie-glaude-jr-phd/the-black-church-is-dead_b_473815.html.

${ }^{5}$ In this essay I am, in part, applying suggestions made by Laurie F. Maffly-Kipp in "The Burdens of Church History," Church History 82, no. 2 (2013), 353-67. According to Maffly-Kipp, church history still works as a category because such categories mattered to historical subjects.

${ }^{6}$ Leslie Harris, In the Shadow of Slavery: African Americans in New York City, 1626-1863 (Chicago: University of Chicago Press, 2003); Nell Irvin Painter, Sojourner Truth: A Life, a Symbol (New York: W. W. Norton, 1996). 
${ }^{7}$ Advocates of black church unity have operated under the shadow of the black theology movement, which has provided a clear and consistent formal theoretical background since the 1960s. On black theology, see James Cone, A Black Theology of Liberation (Philadelphia: Lippincott, 1970), and Cone, Risks of Faith: The Emergence of a Black Theology of Liberation, 1968-1998 (Boston: Beacon Press, 1998). For historical works that present a united and uniformly proreform black religious front, see Craig Steven Wilder, In the Company of Black Men: the African Influence on African American Culture in New York City (New York: New York University Press, 2002); Margaret Washington, Sojourner Truth's America (Urbana: University of Illinois Press, 2009); Graham Russell Hodges, David Ruggles: A Radical Black Abolitionist and the Underground Railroad in New York City (Chapel Hill: University of North Carolina Press, 2012), esp. 8, n 14, n 15; Gary B. Nash, Forging Freedom: the Formation of Philadelphia's Black Community, 1720-1840 (Cambridge, MA: Harvard University Press, 1988). One prominent exception is Graham Russell Hodges, Root and Branch: African Americans in New York and East Jersey, 1613-1863 (Chapel Hill: University of North Carolina Press, 1999). Hodges divides black religious activity into Anglican (activist) and Dutch Reformed (quietist) poles, albeit with most discussion of black experience limited to the former. Scholars such as Nash and Hodges describe white attacks on black attempts at institutional autonomy, which necessarily tends to highlight similarities rather than differences within the black religious community.

${ }^{8}$ One must caution that these institutional and theological imperatives were not final indicators in black religious experience. Black church members and leaders all shared the experience of being black in a society that did not recognize their citizenship and, often, their humanity.

${ }^{9}$ Both groups would grow in visibility and significance later in the antebellum era, and exponentially so after the Civil War, so much so that their experiences often stand in for the black church as a whole. The standard scholarly definition of the black church is typically limited to such historically black denominations of Baptist, Methodist, and Pentecostal; see, for example, C. Eric Lincoln and Lawrence H. Mamiya, The Black Church in the African American Experience (Durham, NC: Duke University Press, 1990); Anne H. Pinn and Anthony B. Pinn, Fortress Introduction to Black Church History (Minneapolis, MN: Fortress Press, 2001).

${ }^{10}$ One interpretation that stresses these trends is Nathan O. Hatch, The Democratization of American Christianity (New Haven, 
CT: Yale University Press, 1989). See also Mark Noll, America's God: From Jonathan Edwards to Abraham Lincoln (New York: Oxford University Press, 2002). On their applications to the black church, see Will B. Gravely, "The Rise of African Churches in America (17861822): Re-examining the Contexts," in African American Religion: Interpretive Essays in History and Culture, ed. Timothy P. Fulop and Albert J. Raboteau (New York: Taylor and Francis, 1997), 133-52.

This was usually the case, but not always. The Denmark Vesey conspiracy is the most prominent exception, as it involved connections with African Methodists, and Nat Turner's charismatic nondenominational (or Baptist?) rebellion was deeply imbued with religious motives. The general truism that denominationalism involved bureaucratic organization, and thus participation within the system, generally holds, however.

${ }^{12}$ A definition of the dialectical model, laid out in sociological terms, is found in Lincoln and Mamiya, The Black Church in the African American Experience, 11-16. Lincoln and Mamiya's work provides a theoretical complement to the historical and theological argument I advance here.

${ }^{13}$ For the more limited definition of black church, see the sources cited in note 8 earlier in this chapter. For my purposes here, the black church refers to any religious body at the congregational level in which a significant, usually majority, percentage of the membership identifies as African American or black. I also include black clergy, whether they minister to predominantly black churches or not, because their messages had ramifications for American blacks, whether part of that respective church or not, and for racial identity in America generally.

${ }^{14}$ Here I follow the distinction created by Curtis Johnson, Islands of Holiness: Rural Religion in Upstate New York, 1790-1860 (Ithaca, NY: Cornell University Press, 1989), 67-70; see also Noll, America's God, 175-76. Johnson called evangelicals formalist and antiformalist based on their connections to and support of transformative reform movements, but the distinction between groups that employed more visible bureaucratic institutional forms and those who downplayed them to call on charismatic forms remains useful outside Johnson's chronological and geographic focus.

${ }^{15}$ Travis Glasson, Mastering Christianity: Missionary Anglicanism and Slavery in the Atlantic World (New York: Oxford University Press, 2011). Older treatments include Frank Klingberg, Anglican Humanitarianism in Colonial New York (Philadelphia: Church Historical Society, 1940); Carl Bridenbaugh, Mitre and Sceptre: Transatlantic Faiths, Ideas, Personalities, and Politics 1689-1775 
(New York: Oxford University Press, 1962); Frederick V. Mills, Bishops by Ballot: An Eighteenth-Century Ecclesiastical Revolution (New York: Oxford University Press, 1978).

${ }^{16}$ A significant minority of Episcopalians were Low Church, and affiliated with evangelical Protestant groups. Because some of them were, like their fellow non-Episcopalian evangelicals, attracted to reform movements, they did interact with their black coreligionists. The High Church position is well developed in Robert Bruce Mullin, Episcopal Vision/American Reality: High Church Theology and Social Thought in Evangelical America (New Haven, CT: Yale University Press, 1986). Evangelical Episcopalians are covered in Diana Hochstedt Butler, Standing against the Whirlwind: Evangelical Episcopalians in Nineteenth-Century America (New York: Oxford University Press, 1995).

${ }^{17}$ See Mullin, Episcopal Vision; Butler, Standing against the Whirlwind.

${ }^{18}$ This description applies specifically to High Church parishes, which tended to numerically dominate and appear to be the party both St. Philip's and St. Thomas (see note 20 ) belonged to.

Histories of both congregations can be found in Robert F. Ulle, "A History of St. Thomas' African Episcopal Church 1794-1865" (Ph.D. Diss., University of Pennsylvania, 1986); and Craig D. Townsend, Faith in Their Own Color: Black Episcopalians in Antebellum New York City (New York: Columbia University Press, 2005). On the subsequent development of other black Episcopalian congregations, see George F. Bragg, The First Negro Priest on Southern Soil (Baltimore: Church and Advocate Print, 1909), 11-12, 24.

${ }^{20} \mathrm{On}$ Williams's early oration and its reception, see Kyle T. Bulthuis, Four Steeples over the City Streets: Religion and Society in New York's Early Republic Congregations (New York: New York University Press, 2014), 106-108. For the texts of his speeches, see Peter Williams, Jr., "An Oration on the Abolition of the Slave Trade," reprinted in Dorothy Porter, ed., Early Negro Writing 1760-1837 (Boston: Beacon Press, 1971), 344-45; Peter Williams, Jr., "To the Citizens of New York," in Carter G. Woodson, ed., The Mind of the Negro as Reflected in Letters Written during the Crisis (1926; reprint, New York: Russell and Russell, 1969), 630-34.

${ }^{21}$ William Douglass, Sermons Preached in the African Protestant Episcopal Church of St. Thomas' Philadelphia (Philadelphia: King and Baird, 1854)

${ }^{22}$ On St. Thomas's composition, see Ulle, "History of St. Thomas' African Episcopal Church." For St. Philip's, see Townsend, Faith in Their Own Color, esp. Appendix, "Parishioners of 
St. Philip's Church," 199-202. More on St. Philip's social composition is available in Bulthuis, Four Steeples over the City Streets, 140-43, 147-54, 172-78.

${ }^{23}$ The aim of education was prominently emphasized in nearly every black religious body in America; it was the province of no single denomination. Black Episcopalians, however, were among the earliest and most prominent supporters, and, alongside black Presbyterians, the most forceful voices.

${ }^{24}$ C. Peter Ripley, ed. The Black Abolitionist Papers, vol. 3, The United States, 1830-1846 (Chapel Hill: University of North Carolina Press, 1991), 189, 195-96, 337-38, 471, 473. 405,472 .

${ }^{25}$ Ripley, Black Abolitionist Papers, 96, 188, 195-98, 224-25, 472.

${ }^{26}$ Ripley, Black Abolitionist Papers, 24-26, 190, 195-98, 401-402,

${ }^{27}$ Townsend, Faith in Their Own Color, 53-58, 97-98; Ulle, "History of St. Thomas," 238-39, 341-42.

${ }^{28}$ This was the case at St. Philip's, St. Thomas, and St. James in Baltimore. See Townsend, Faith in Their Own Color, esp. 98-107; William Douglass, Annals of the First African Church, in the United States of America, Now Styled The African Episcopal Church of St. Thomas, Philadelphia (Philadelphia: King and Baird, 1862), esp. 118-33, George F. Bragg, The First Negro Priest on Southern Soil (Baltimore: Church and Advocate Print, 1909), esp. 19-34.

${ }^{29}$ In his volume of sermons, William Douglass, Sermons Preached in the African Protestant Episcopal Church of St. Thomas', Philadelphia, offers a series of messages that are highly literate, beautifully composed, and completely silent on political issues of the day. Douglass's frequent condemnations of sin and sinfulness, however, may have served a clearer message to his black parishioners.

${ }^{30}$ Ripley, Black Abolitionist Papers, 56, 198, 350-51.

${ }^{31}$ Wilson Moses, Alexander Crummell: A Study of Civilization and Discontent (New York: Oxford University Press, 1989); Ripley, ed., Black Abolitionist Papers, 286, 401-402; W. E. B. Du Bois, "Of Alexander Crummell," in Souls of Black Folk (1903; reprint, New York, Simon and Schuster, 2005), chapter 12.

${ }^{32}$ On Black Atlantic Calvinism, see anthologies by Joanna Brooks and John Saillant, eds., "Face Zion Forward": First Writers of the Black Atlantic, 1785-1798 (Boston: Northeastern University Press, 2002); Vincent Carretta and Philip Gould, eds., Genius in Bondage: Literature of the Early Black Atlantic (Lexington: University Press of Kentucky, 2001); Vincent Carretta, ed., Unchained Voices: An Anthology of Black Authors in the English-Speaking World of the Eighteenth Century (Lexington: University Press of Kentucky, 2003). 
See also James Sidbury, Becoming African in America: Race and Nation in the English Black Atlantic (New York: Oxford University Press, 2007). For biographical examples of black Presbyterians and Congregationalists, see David E. Swift, Black Prophets of Justice: Activist Clergy before the Civil War (Baton Rouge: Louisiana State University Press, 1989).

${ }^{33}$ On Calvinism in America, see E. Brooks Holifield, Theology in America: Christian Thought from the Age of the Puritans to the Civil War (New Haven, CT: Yale University Press, 2003); see also Mark Noll, America's God, esp. 253-68. On reformist Calvinists generally, see Leo P. Hirrel, Children of Wrath: New School Calvinism and Antebellum Reform (Lexington: University Press of Kentucky, 1998).

${ }^{34}$ Ripley, Black Abolitionist Papers, 439. On black interaction with such theology, see Christopher Cameron, To Plead Our Own Cause: African Americans in Massachusetts and the Making of the Antislavery Movement (Kent, OH: Kent State University Press, 2014); Swift, Black Prophets of Justice, 8-9. On abstractions in preaching, one observer noted that Presbyterian minister Andrew Harris, of Philadelphia, was "more a discriminating logician than a fanciful poet." Ripley, Black Abolitionist Papers, 296-97.

${ }^{35}$ Christopher Cameron, "The Puritan Origins of Black Abolitionism in Massachusetts," Historical Journal of Massachusetts 39, no. 1-2 (Summer 2011), 79-107.

${ }^{36}$ Congregational demands for a just community mitigated the atomizing forces that a Congregationalist-based polity might create; in general, New England Congregationalists acted in more concert than, for example, Baptists, whose decentralization often meant less action on the national level.

${ }^{37}$ Swift, Black Prophets of Justice, 15, 17.

${ }^{38}$ On Marrant's nationalism, see the introduction in Brooks and Saillant, eds., "Face Zion Forward"; For Haynes, see Cameron, "Puritan Origins," 90, 92; John Saillant, Black Puritan, Black Republican: The Life and Thought of Lemuel Haynes, 1753-1833 (New York: Oxford University Press, 2002). For the radical implications of Haynes's preaching, see John Saillant, "Lemuel Haynes and the Revolutionary Origins of Black Theology, 1776-1801," Religion and American Culture 2, no. 1 (Winter 1992), 79-102, esp. 91-93. Ripley, ed., Black Abolitionist Papers, 218-19; James W. C. Pennington, A Textbook of the Origin and History of the Colored People (Hartford, CT: L. Skinner, 1841) and Pennington, The Fugitive Blacksmith, or, Events in the History of James W. C. Pennington, Pastor of a Presbyterian Church in New York, 2nd ed. (London: Gilpin, 1849). 


\author{
${ }^{39}$ Ripley, Black Abolitionist Papers, 17, 177, 187, 199, 454-45, 466, \\ $477,482$. \\ ${ }^{40}$ David Swift, Black Prophets of Justice; Ripley, Black Abolitionist
} Papers, 95, 187, 218-29, 336, 343, 439, 466, 477. See, particularly, Henry Highland Garnet, Memorial Discourse, Delivered in the Hall of the House of Representatives, Washington City D.C. on Sabbath, February 12, 1865 (Philadelphia: Joseph M. Wilson, 1865).

${ }^{41}$ Cameron, "Puritan Origins," 80-82, 92-94; Ripley, Black Abolitionist Papers, 50.

${ }^{42}$ Mechal Sobel, Trabelin' On: The Slave Journey to an Afro-Baptist Faith (Westport, CT: Greenwood Press, 1979), 134; Ripley, Black Abolitionist Papers, 212, 199.

${ }^{43}$ Ripley, Black Abolitionist Papers, 23, 187, 296-97; Aileen S. Kraditor, Means and Ends in American Abolitionism: Garrison and His Critics on Strategy and Tactics, 1834-1840 (New York: Pantheon Books, 1969).

${ }^{44}$ Some church historians of Europe or of an earlier era might be surprised at this connection, because in the colonial era, Episcopalians and Presbyterians were often political and theological enemies; see Patricia U. Bonomi, Under the Cope of Heaven: Religion, Society, and Politics in Colonial America (New York: Oxford University Press, 1986), 198-99. After the Revolution, however, their similarities were greater than their differences, especially when facing large numbers of new religious movements who challenged those groups' traditional authority. Such is the general point of Hatch, Democratization.

${ }^{45}$ Swift, Prophets of Justice, 17. In this connection between Episcopalians and Presbyterians, I borrow from Curtis D. Johnson, whose work, Islands of Holiness, makes the distinction between formalist and antiformalist groups, pp. 67-70.

${ }^{46}$ Cornish quote in Ripley, Black Abolitionists, 15 . The concept of uplift is the central focus of Patrick Rael, Black Identity and Black Protest in the Antebellum North (Chapel Hill: University of North Carolina Press, 2002), esp. 119-56. See also Dickson D. Bruce Jr., The Origins of African American Literature, 1680-1865, (Charlottesville: University Press of Virginia, 2001); Stephen G. Hall, A Faithful Account of the Race: African American Historical Writing in Nineteenth-Century America (Chapel Hill: University of North Carolina Press, 2009).

${ }^{47}$ On African identity, see Sidbury, Becoming African in America.

${ }^{48}$ On Methodism, see John Wigger, Taking Heaven by Storm: Methodism and the Rise of Popular Christianity in America (New York: Oxford University Press, 1998); Dee Andrews, The Methodists in 
Revolutionary America 1760-1800 (Princeton, NJ: Princeton University Press, 2000).

${ }^{49}$ Methodism contained ecclesiastical hierarchy in part because it began as a movement within the Anglican church; hence the title of the white-run church included the phrase Methodist Episcopal, and of the black churches, African Methodist Episcopal. The development toward greater hierarchy in the black churches is described in Henry H. Mitchell, Black Church Beginnings: The Long-Hidden Realities of the First Years (Grand Rapids, MI: Eerdman's, 2004) 104-15.

${ }^{50}$ These tensions are dealt with in a number of works; see, for example, Andrews, Methodists, 93-95.

${ }^{51}$ On Barsary, see Bulthuis, Four Steeples, 66; for Truth, see Margaret Washington, Sojourner Truth's America; Lee's autobiography is conveniently reprinted in William L. Andrews, ed., Sisters of the Spirit: Three Black Women's Autobiographies of the Nineteenth Century (Bloomington: Indiana University Press, 1986).

${ }^{52}$ Newman, Freedom's Prophet, 229-34; Sojourner Truth with Olive Gilbert, Narrative of Sojourner Truth: A Bondswoman of Olden Time (1878; reprint, New York: Arno Press, 1968), 79-81.

${ }^{53}$ Sobel, Trabelin' On, 143; Daniel Alexander Payne, Recollections of Seventy Years, 93-94, 80-81; see also Clarence E. Walker, Rock in a Weary Land: The African Methodist Episcopal Church during the Civil War and Reconstruction (Baton Rouge: Louisiana State University Press, 1982).

${ }^{54}$ Newman, Freedom's Prophet, 7, 38-39; Mitchell, Black Church Beginnings, 108-109; Ripley, Black Abolitionist Papers, 296-97; Hodges, David Ruggles, 7, 110; Payne, Recollections, 233-41.

${ }^{55}$ The Doctrines and Discipline of the African Methodist Episcopal Church, 1st ed. (Philadelphia: John H. Cunningham, 1817), 87, 76-77; The Doctrines and Discipline of the African Methodist Episcopal Church, in America, Established in the City of New-York, October 25, 1820, 2nd ed. (New York: Joseph M. Marsh, 1841), 55.

${ }^{56}$ Hodges, David Ruggles, 112-13; Ripley, Black Abolitionist Papers, 176, 180, 285-86.

${ }^{57}$ See, for example, The Doctrines and Discipline, 2nd ed., p. 23.

${ }^{58}$ On Methodist prominence in the early Republic antislavery movement, see, for example, Donald G. Mathews, Slavery and Methodism: A Chapter in American Morality, 1780-1845 (Princeton, NJ: Princeton University Press, 1965); for early immediatist efforts beyond 1830 and Methodist involvement, see Howard Holman Bell, ed., Minutes of the Proceedings of the National Negro Conventions 18301864 (New York: Arno Press, 1969). One prominent Methodist example of the emphasis on sanctification over reform is that of 
George White, whose narrative is reprinted in Graham Russell Hodges, ed., Black Itinerants of the Gospel: The Narratives of John Jea and George White (Madison, WI: Madison House, 1993). See also Walker, Rock in a Weary Land.

${ }^{59}$ Frederick Douglass, Life and Times of Frederick Douglass, Written by Himself (1893), reprinted in Frederick Douglass: Autobiographies, ed. Henry Louis Gates Jr. (New York: Library of America, 1994), 913-14; Ripley, Black Abolitionist Papers, 96, 259-60, 359-60, 452, 455. Thus, black Episcopalian James McCune Smith worshipped in a nominally biracial church, but supported segregated political action; African Methodist Frederick Douglass worshipped in a black church, but supported integrated social institutions. In some cases religious identity could spur action different from the immediate institutional or environmental imperatives.

${ }^{60}$ Even this statement requires some qualification; within any religious affiliation in the colonial and early Republic eras, black groups, even those most localized, displayed interaction with larger bodies. David George's narrative, for example, was initially published via white English Baptist channels; this narrative has been reprinted in Vincent Carretta, ed., Unchained Voices: An Anthology of Black Authors in the English-Speaking World of the Eighteenth Century (Lexington: University Press of Kentucky, 2003).

${ }^{61}$ Jewel L. Spangler, "Becoming Baptists: Conversion in Colonial and Early National Virginia," Journal of Southern History 67, no. 2 (May 2001), 243-86; Johnson, Islands of Holiness, 67-70; Sobel, Trabelin' On, 80-90; Eugene D. Genovese, Roll Jordan Roll: The World the Slaves Made (New York: Pantheon Books, 1974), 283. Some Ohio black Baptists, however, were among the first to form antislavery societies.

${ }^{62}$ Cameron, To Plead Our Own Cause; Ripley, ed., Black Abolitionist Papers, 270, 316. Again, the Baptist example includes exceptions that allowed for interracial cooperation; see Ripley, Black Abolitionist Papers, 268, 317-19.

${ }^{63}$ Mark Noll, America's God, 148-49.

${ }^{64}$ Mechal Sobel, Trabelin' On, representative examples throughout the work, but see esp. 140-44; see also Michael A. Gomez, Exchanging Our Country Marks: The Transformation of African Identities in the Colonial and American South (Chapel Hill: University of North Carolina Press, 1998). An earlier articulation that emphasizes black religious difference from white, some of it attributable to Africa, is Eugene D. Genovese, Roll Jordan Roll, esp. 232-84. 
${ }^{65}$ One argument that minimizes African cultural survivals in detailing this process is Winthrop S. Hudson, "The American Context as an Area for Research in Black Church Studies," Church History 52, no. 2 (June 1983), 157-71. See also Hatch, Democratization, 102-13, for a work that largely assumes democratic parallels between white and black religious experiences, even as it acknowledges white racism and black church separation. Hudson's article clearly minimized anthropological findings that have grown in significance the past three decades. I suggest that the two developmentsAfrican cultural survivals and parallels with white religious practices - are not mutually exclusive. A fine study that includes both is Mechal Sobel, The World They Made Together: Black and White Values in Eighteenth-Century Virginia (Princeton, NJ: Princeton University Press, 1987). See also Gravely, "The Rise of African Churches in America," 133-52.

${ }^{66}$ The example of the Moravians serves as a sort of forerunner to the Baptists in their racial inclusivity; on the Moravians, see Jon F. Sensbach, A Separate Canaan: The Making of an Afro-Moravian World in North Carolina, 1763-1840 (Chapel Hill: University of North Carolina Press, 1998). See also Jon F. Sensbach, Rebecca's Revival: Creating Black Christianity in the Atlantic World (Cambridge, MA: Harvard University Press, 2005). For early Baptist support of interracial worship, see Rhys Isaac, The Transformation of Virginia, 1740-1790 (Chapel Hill: University of North Carolina Press, 1982). See also Sobel, Trabelin' On, 363; Sobel, World They Made Together. Examples of Baptist interracialism also occur in James B. Taylor, Virginia Baptist Ministers, series II (Philadelphia: J. B. Lippincott, 1859), 109, 124-27, 396, 440-41.

${ }^{67}$ Genovese, Roll Jordan Roll, 263; Mitchell, Black Church Beginnings, 115; James Sidbury, Ploughshares into Swords: Race, Rebellion, and Identity in Gabriel's Virginia, 1730-1810 (Cambridge, England: Cambridge University Press, 1997); Randolph Scully, Religion and the Making of Nat Turner's Virginia: Baptist Community and Conflict, 1740-1840 (Charlottesville: University of Virginia Press, 2008).

${ }^{68}$ Taylor, Virginia Baptist Ministers, Series II, 56, 192-94, 474-76; Morte's story is recounted in Albert J. Raboteau, Slave Religion: The "Invisible Institution" in the Antebellum South (1978; rev. ed. New York: Oxford University Press, 2004), 316-17.

${ }^{69}$ Ripley, Black Abolitionist Papers, 304, 447.

${ }^{70}$ Mitchell, Black Church Beginnings, 116-17, 119-20.

${ }^{71}$ On the birth of the Pentecostal church, see Mitchell, Black Church Beginnings, 177-79. Nathan Hatch invoked Pentecostalism as 
an example of continued populist impulses in American religion; see Hatch, Democratization, pp. 214-19. The leadership of black Baptists in the Civil Rights movement is covered in a range of works; among them, see Clarence Taylor, Black Religious Intellectuals: The Fight for Equality from Jim Crow to the Twenty-First Century (New York: Routledge, 2002).

For a brief recapitulation of these positions, see note 5 .

${ }^{73}$ Scholars' tendency to limit the black church to the historically black denominations of Baptist, Methodist, and Pentecostal has often been accompanied by assumptions of natural affinity or essentialist identification. A southern folk saying suggests "if a nigger ain't a Baptist, someone has been tampering with his religion" - see Sobel, Trabelin' On, 79. This generalized stance has been attributed to Booker T. Washington's more refined "if a black man is anything but a Baptist or a Methodist, someone has been tampering with his religion"; cited in Harold T. Lewis, Yet with a Steady Beat (Valley Forge, PA: Trinity Press, 1996), 1, 14; and Townsend, Faith in Their Own Color, 38-40. As historians of black Episcopalianism, Lewis and Townsend work in the shadow of the much more numerous black Baptist and Methodist bodies.

${ }^{74}$ I have extrapolated some inferences on numbers from the appendix of Kyle Roberts, Evangelical Gotham: Religion and the Making of New York City, 1783-1860 (Chicago: University of Chicago Press, 2016), 273, Appendix A.5. Roberts's emphasis on evangelicalism arrays the Presbyterians alongside the Methodists and Baptists, against the comparatively few black Episcopalians. My emphasis here on formalist versus antiformalist denominational structures renders a slightly more equal, but still highly imbalanced, fissure. These numerical differences parallel those among American Christians as a whole; see Roger Finke and Rodney Stark, The Churching of America, 1776-1990: Winners and Losers in Our Religious Economy (New Brunswick, NJ: Rutgers University Press, 1992).

One should account for individual choice within these larger structures. Black Episcopalians were not uniformly quietist, even though that denomination's liturgical tradition generally encouraged reflection and literacy as primary tools. Episcopalian clergy were largely hamstrung by limits placed on them by church hierarchy. Perhaps as a consequence of these limits, seeing their minsters rendered silent, black Episcopalian laity such as George T. Downing and James McCune Smith offered striking acts of resistance with pen and tongue. In similar ways, each denominational body created a range of possibilities that individual believers and church leaders 
alike acted upon. No church affiliation mandated a simple and definite political trajectory, although tendencies did appear.

${ }^{76}$ Examples of such include Karen McCarthy Brown, Mama Lola: A Vodou Priestess in Brooklyn, rev. ed. (Berkeley, CA: University of California Press, 2001); Edward E. Curtis IV, Black Muslim Religion in the Nation of Islam, 1960-1975 (Chapel Hill: University of North Carolina Press, 2006); Jacob Dorman, Chosen People: The Rise of American Black Israelite Religions (New York: Oxford University Press, 2013); J. Lorand Matory, Black Atlantic Religion: Tradition, Transnationalism, and Matriarchy in the Afro-Brazilian Candomble (Princeton, NJ: Princeton University Press, 2005).

A BSTRACT Scholars of African-American religious history have recently debated the significance of the black church in American history. Those that have, pro and con, have often considered the black church as a singular entity, despite the fact that African Americans affiliated with a number of different religious traditions under the umbrella of the black church. This article posits that it is useful to consider denominational and theological developments within different African-American churches. Doing so acknowledges plural creations and developments of black churches, rather than a singular black church, which better accounts for the historical experience of black religion. In this piece, I analyze four different denominational and theological traditions that blacks followed in the early Republic: the Anglican-Episcopalian, the Calvinist (CongregationalPresbyterian), the Methodist, and the Baptist. Each offered a unique ecclesiastical structure and set of theological assumptions within which black clergy and laity operated. Each required different levels of interaction with white coreligionists, and, although some tended to offer more direct opportunities for reform and resistance, all groups suffered differing constraints that limited such action. I argue that the two bodies connected to formalist traditions, the Episcopalian and Calvinist, were initially better developed despite their smaller size, and thus disproportionately shaped black community and reform efforts in the antebellum United States. 